\title{
KEANEKARAGAMAN ARTROPODA PREDATOR DI AGROEKOSISTEM SAWAH PADA BERBAGAI GALUR PADI POLITEKNIK NEGERI LAMPUNG
}

\section{DIVERSITY OF PREDATOR ARTHTOPODS IN RICE FIELD AGROECOSYSTEMS ON VARIOUS ASSEMBLED RICE LINES OF POLITEKNIK NEGERI LAMPUNG}

\author{
Lina Budiarti*, Jaenudin Kartahadimaja, Miranda Ferwita Sari, Destieka Ahyuni, \\ Dulbari
}

\author{
Jurusan Budidaya Tanaman Pangan, Politeknik Negeri Lampung \\ Jl. Soekarno Hatta No. 10, Rajabasa Raya, Kec. Rajabasa, Bandar Lampung, Lampung 35144
}

*Korespondensi: linabudiarti@polinela.ac.id

\begin{abstract}
ABSTRAK
Artropoda predator dapat dioptimalkan perannya di ekosistem sawah untuk menekan populasi hama. Tujuan dari penelitian ini adalah untuk menganalisis nilai indeks keanekaragaman artropoda predator pada galur padi rakitan Politeknik Negeri Lampung. Penelitian ini telah dilaksanakan pada bulan Agustus-Desember 2020. Penelitian dilaksanakan di lahan Seed Teaching Farm Program Studi Teknologi Perbenihan, Politeknik Negeri Lampung dengan galur padi Pandan Wangi (PW), Ciherang (CH), B1, B2, B3, B4, B7, D2, D3, F3, F4, H1, H4, K, dan L2 dengan 2 varietas unggul pembanding yaitu Ciherang $(\mathrm{CH})$ dan Gilirang (Gil). Pengamatan artropoda dilakukan menggunakan metode jaring dilakukan sebanyak 3 ayunan ganda. Pengambilan sampel serangga dilakukan pada pukul 06.0009.00 WIB. Identifikasi menggunakan makroskop binokuler di Laboratorium tanaman pangan II. Data hasil identifikasi serangga kemudian dihitung nilai indeks keanekaragaman spesies Shannon $\left(\mathrm{H}^{\prime}\right)$, indeks dominasi spesies Berger-Parker (d) dan indeks kemerataan spesies dari Pielou (E). Hasil pengamatan menunjukkan bahwa artropoda predator yang ditemukan adalah laba-laba predator seperti Oxyopes javanus, Tetragnatha javana, T. virescens, T. maxilosa, Pardosa pseudoannulata, Athypena sp., dan serangga predator seperti Microvelia douglasi, Agriocnemis pygmaea, A. femina, A. pieris, dan Verania lineata, Menochillus sexmachulatus, Hispella atra, dan Paederus fuscipes. Nilai indeks keanekaragaman pada setiap galur padi fluktuatif dan berkisar dari rendah ke sedang.

Kata kunci: artropoda predator, indeks keanekaragaman, dan galur padi
\end{abstract}

\begin{abstract}
The role of predatory arthropods can be optimized in the paddy field ecosystem to reduce pest populations. The purpose of this study was to analyze the diversity index value of predatory arthropods on assembled rice lines at Politeknik Negeri Lampung. This research was conducted in August-December 2020. The research was carried out in the Seed Teaching Farm of the Seed Technology Study Program, Politeknik Negeri Lampung with Pandan Wangi (PW), Ciherang (CH), B1, B2, B3 rice lines. B4, B7, D2, D3, F3, F4, H1, H4, K, and L2 with 2 superior varieties, namely Ciherang (CH) and Gilirang (Gil). Arthropod observations were carried out using the net method with 3 double swings. Insect sampling was conducted at 06.00-09.00 WIB. Identification using binocular macroscopes in the food plant laboratory II. The insect identification data then calculated the Shannon species diversity index ( $\mathrm{H}$ '), the Berger-Parker species dominance index (d) and the Pielou species evenness index (E). The results showed that the predatory arthropods found were predatory spiders such as Oxyopes javanus, Tetragnatha javana, T. virescens, T. maxilosa, Pardosa pseudoannulata, Athypena sp., and predatory insects such as Microvelia douglasi, Agriocnemis pygmaea, A. femina, A. Pieris, and Verania lineata, Menochillus sexmachulatus, Hispella atra, and Paederus fuscipes. The value of the diversity index for each rice line fluctuates and ranges from low to medium.
\end{abstract}

Keywords: predatory arthropods, diversity index, and rice lines. 


\section{PENDAHULUAN}

Serangan hama menjadi salah satu faktor pembatas dalam meningkatkan produksi padi. Hama dapat menyebabkan kehilangan hasil sehingga petani mengalami kerugian. Akibat serangan hama maka akan menambah biaya produksi. Hal ini mengingat bahwa hama menyerang tanaman padi dari mulai pembibitan hingga pasca panen. Beberapa hama seperti wereng coklat menjadi hama penting nasional yang menjadi kendala pada budidaya tanaman padi karena menyebabkan batang tanaman menjadi mudah rebah akibat cairan tanaman karena dihisap oleh wereng coklat dan malai padi menjadi hampa (Baehaki, 2012). Selain menghisap cairan batang, hama wereng coklat juga mendapatkan perhatian karena wereng coklat dapat menjadi vektor virus (Baehaki, 2011). Virus yang ditularkan seperti virus kerdil rumput yang menyebabkan tanaman padi menjadi kerdil dan tidak menghasilkan malai. Akibatnya dari virus ini maka menyebabkan penurunan produksi padi dan bahkan menyebabkan puso (Baehaki dan Mejaya, 2014).

Petani selalu mengandalkan pestisida sintetik untuk mengendalikan populasi hama. Aplikasi pestisida sintetik dilakukan oleh sebagian besar petani padi di Indonesia. Pengendalian hama dengan pestisida sintetik dilakukan secara terus menerus tanpa memperhatikan residu dapat memberikan dampak negatif. Aplikasi insektisida kimia tidak hanya membunuh hama sasaran tetapi juga membunuh serangga non target seperti predator ataupun parasitoid yang menjadi musuh alami bagi hama tanaman padi di lapangan (Fitriani, 2016). Di ekosistem alami keberadaan musuh alami ini sangat penting dalam menekan populasi hama. Peningkatan populasi hama diekosistem alami yang diiringi dengan peningkatan populasi dan keanekaragaman musuh alami mampu menekan populasi hama sampai dibawah ambang ekonomi. Hal ini akibat berlangsungnya rantai makanan yang

berjalan di ekosistem tersebut yang menyebabkan ekosistem menjadi stabil.

Musuh alami seperti artropoda predator diekosistem sawah memiliki peran penting dalam menekan populasi hama padi. Artropoda predator dapat dioptimalkan perannya diekosistem sawah untuk menjaga agar tidak terjadi ledakan populasi hama. Artropoda predator di ekosistem sawah menjadi sasaran non target aplikasi pestisida kimia yang dilakukan oleh petani. Laba-laba dari ordo Arachnida sering dijumpai pada tajuk tanaman padi. Laba-laba merupakan artropoda predator yang memangsa hama dan memangsa semua jenis hama. Labalaba yang menjadi artropoda predator memiliki spesies yang melimpah dan dari 
berbagai famili. Laba-laba ini aktif mencari mangsa. Keberadaan laba-laba di ekosistem sawah sangat berperan dalam menjaga populasi hama agar tidak terjadi ledakan populasi hama. Menurut Khodijah et al. (2012) menyatakan bahwa populasi laba-laba diekosistem dapat membunuh hama wereng di tanaman padi. Populasi laba-laba ini yang menjadi sasaran non target akibat aplikasi insektisida yang tidak bijaksana. Tubuh laba-laba yang lunak dan keberadaannya banyak pada tajuk tanaman padi menjadikan laba-laba ini mudah terbunuh oleh aplikasi insektisida. Artropoda lain yang berperan dalam menekan populasi hama adalah serangga predator. Hal ini Hendrival et al., (2017) menyatakan bahwa musuh alami hama seperti laba-laba sangat peka terhadap aplikasi beberapa bahan aktif insektisida kimia sehingga menyebabkan keanekaragaman artropoda predator menurun. Serangga predator ini mampu memangsa hama-hama tanaman padi. Serangga predator dari ordo Coleoptera, Hemiptera, Odonata juga banyak dijumpai diekosistem sawah dan menjadi serangga non target akibat aplikasi insektisida.

Peran artropoda predator diekosistem sawah perlu diperkenalkan dan diketahui oleh petani padi. Penggunaan pestisida kimia yang tinggi juga disebabkan salah satunya akibat petani tidak memahami peran artropoda predator diekosistem sawah. Petani tidak memahami dan mengetahui jenis artropoda predator apa saja yang dapat menekan populasi hama padi. Oleh karena itu perlu kajian yang lebih banyak tentang jenis atropoda predator yang dapat dimanfaatkan sebagai musuh alami. Kajian meliputi jenis spesies artropoda predator, banyaknya individu artropoda predator, nilai indeks keanekaragaman untuk melihat banyaknya jenis artropoda predator, nilai dominasi spesies dan kemerataan spesies artropoda predator agar diketahui nilai indeks keanekaragaman. Ekosistem alami dengan nilai indeks keanekaragaman yang tinggi menggambarkan bahwa ekositem alami tersebut stabil. Stabilnya ekosistem alami maka ledakan populasi hama dapat dicegah.

\section{BAHAN DAN METODE}

\section{Pengumpulan Data}

Penelitian ini telah dilaksanakan pada bulan Agustus-Desember 2020 . Penelitian dilaksanakan dilahan Seed Teaching Farm Program Studi Teknologi Perbenihan, Jurusan Budidaya Tanaman Pangan, Politeknik Negeri Lampung. Pada penelitian ini digunakan galur padi hasil rakitan Politeknik Negeri Lampung yaitu Pandan Wangi (PW), Ciherang (CH), B1, B2, B3, B4, B7, D2, D3, F3, F4, H1, H4, K, dan L2 dengan 2 varietas unggul pembanding yaitu Ciherang $(\mathrm{CH})$ dan Gilirang (Gil). Budidaya padi dilakukan 
secara konvensional dengan pengendalian organisme pengganggu tanaman (OPT) menggunakan insektisida kimia sesuai dengan kebiasaan petani. Lahan yang digunakan seluas dan dibagi menjadi 3 kelompok. Setiap kelompok ditanami 30 rumpun padi dengan jarak tanam $20 \mathrm{~cm} \mathrm{x}$ $20 \mathrm{~cm}$.

\section{Pengamatan Artropoda Predator}

Pengamatan artropoda dilakukan menggunakan metode jaring serangga yang dilakukan sebanyak 3 ayunan ganda setiap plot sampel. Pengambilan sampel serangga dilakukan pada pukul 06.0009.00 WIB. Serangga yang didapatkan kemudian dimasukkan kedalam kantong plastik berukuran $12 \mathrm{~cm} \mathrm{x} 25 \mathrm{~cm}$ yang berisi alkohol 70\% yang diberi label dan dibawa ke Laboratorium Tanaman Pangan II untuk dibersihkan dan diidentifikasi menggunakan makroskop binokuler. Untuk identifikasi serangga digunakan acuan buku deGunst (1957), Kalshoven (1981), Lawrence dan Britton (1994), Hadlington dan Jhonston (1987), Barrion \& Litsinger (1990), Hilsenhoff (1991), Shepard et al. (1991), dan Barrion \& Litsinger (1995). Pengambilan sampel serangga dilakukan pada umur padi 14,28 , 42 dan 56 hari setelah tanam (HST).

\section{Analisis Data}

Data hasil identifikasi serangga kemudian dihitung nilai indeks keanekaragaman spesies Shannon ( $\left.\mathrm{H}^{\prime}\right)$, indeks dominasi spesies Berger-Parker (d) dan indeks kemerataan spesies dari Pielou (E) menggunakan buku Magurran (1987).

\section{HASIL DAN PEMBAHASAN}

Pada pengamatan artropoda predator umur padi 14 HST diketahui bahwa spesies artropoda predator yang ada di ekosistem sawah adalah kelompok laba-laba seperti Oxyopes javanus, Tetragnatha javana, $T$. virescens, $T$. maxilosa, Athypena sp., dan Pardosa pseudoannulata. Hal ini sesuai dengan penelitian yang dilakukan oleh Hendrival et al. (2017) yang menyatakan bahwa famili laba-laba yang ditemukan di ekosistem sawah adalah Oxyopidae, Tetragnathidae, dan Lycosidae. Untuk serangga predator yang ditemukan dilahan sawah seperti Microvelia douglasi, Agriocnemis pygmaea, A. femina, A. pieris, dan Verania lineata. Pada pengamatan artropoda predator di galur-galur padi hasil rakitan Politeknik Negeri Lampung diketahui bahwa galur padi B7 dan F4 tidak ditemukan artropoda predator yang menghuni tajuk tanaman padi (Tabel 1).

Pengamatan artropoda predator pada umur padi 28 HST diketahui bahwa populasi artropoda predator tidak ditemukan pada galur padi Gil, B4, B7, D2, dan H1. Ada 3 galur padi rakitan Politeknik Negeri Lampung dan 1 varietas pembanding yang tidak ditemukan populasi artropoda predator. Populasi 
artropoda predator jumlahnya masih sedikit. Hal ini disebabkan karena umur tanaman padi yang masih kecil sehingga populasi hama masih rendah sehingga populasi artropoda predator juga masih sedikit. Pada pengamatan artropoda predator umur padi 28 HST spesies serangga predator $M$. douglasi tidak ditemukan seperti pada pengamatan umur padi 14 HST. Tetapi spesies dari ordo Coleoptera famili Chrysomellidae Hispella atra ditemukan pada galur padi B2 (Tabel 2). Sedikitnya artropoda predator yang ditemukan pada pengamatan ini disebabkan oleh budidaya tanaman yang dilakukan masih secara konvensional. Aplikasi insektisida untuk mengendalikan populasi hama pada tanaman padi akan memberikan dampak terhadap nilai indeks keanekaragaman yang rendah. Hal ini sejalan dengan Hendrival et al. (2017) yang menyatakan bahwa sistem budidaya sangat mempengaruhi nilai indeks keanekaragaman. Herlinda et al. (2008) menyatakan bahwa nilai indeks keanekaragaman artropoda predator penghuni tanah sangat tinggi nilainya pada lahan yang tidak diberikan aplikasi pestisida kimia.

Pengamatan artropoda predator umur padi 42 HST diketahui bahwa labalaba famili Tetragnathidae T. javana, $T$. virescens, T. maxilosa banyak dijumpai pada semua galur padi. Herlinda et al. (2015) menyatakan bahwa artropoda predator pada tajuk tanaman yang banyak ditemukan adalah laba-laba dari famili Lycosidae dan Araneidae. Selain itu ordo Odonata famili Coenagrionidae $A$. pygmaea, A. femina, dan A. pieris. Keberadaan serangga predator tersebut juga banyak ditemukan di galur padi hasil rakitan Politeknik Negeri Lampung. Artropoda predator dari famili Lycosidae Athypena sp., P. pseudoannulata dan famili Correidae M. douglasi tidak dijumpai pada pengamatan ini. Pada pengamatan artropoda predator umur padi 42 HST juga ditemukan spesies predator dari famili Staphylinidae Paederus fuscipes yang dikenal oleh petani dengan nama tomcat (Tabel 3). P. fuscipes ini dapat menekan populasi hama karena aktif mencari mangsa. Menurut Arifin (2012) P. fuscipes merupakan predator yang dapat memangsa hampir semua jenis hama dan memangsa hampir semua stadia serangga. $P$. fuscipes memangsa hama seperti wereng coklat ataupun wereng hijau. Wereng coklat dan wereng hijau memiliki habitat yang berbeda di tanaman padi. Wereng coklat meyerang pangkal batang padi, sedangkan wereng hijau menyerang daun tanaman padi dengan cara menghisap cairan tanaman. Zuharah dan Maryam (2020) menyatakan bahwa P. fuscipes memangsa Reselia dorsalis, Nilaparvata lugens, dan Nephotettix virescens sehingga ekosistem menjadi stabil. 
Populasi artropoda predator ditemukan pada semua galur padi umur 56 hst. Populasi artropoda predator $P$. fuscipes banyak ditemukan diumur padi 56 hst dibandingkan pada umur tanaman padi 14-42 HST. Selain $P$. fuscipes, serangga predator dari ordo Coleoptera famili Coccinellidae juga ditemukan 2 spesies yaitu Verania lineata dan Menochillus sexmachulatus pada galur padi B2 dan B4. Populasi artropoda predator yang paling banyak ditemukan disemua galur padi umur 56 HST adalah laba-laba dari famili Tetragnathidae dengan spesies T. javana, T. virescens, dan T. maxilosa serta serangga predator yang banyak ditemukan dari famili Coenagrionidae $A$. pygmaea, A. femina, dan A. pieris (Tabel 4). Laba-laba famili Tetragnathidae merupakan laba-laba yang banyak ditemukan pada tajuk tanaman padi. Labalaba merupakan predator yang dapat memangsa semua jenis hama. Menurut Kurniawati (2015) famili Coenagrionidae merupakan serangga predator yang banyak dijumpai di lahan yang ditanami tanaman berbunga dibandingkan tanaman monokultur. Stadia pra dewasa dan imago famili Coenagrionidae berperan sebagai predator. Stadia pra dewasa dari famili Coenagrionidae dikenal dengan sebutan naiad. Imago aktif mencari mangsa serangga yang terbang atau pada tajuk tanaman. Naiad memangsa serangga yang ada di air. Naiad memiliki morfologi yang berbeda dengan imago. Imago dari famili Coenagrionidae aktif terbang mencari mangsa (Amrullah, 2018). Sedangkan naiad merupakan stadia pra dewasa famili Coenagrionidae yang hidup di air. Oleh karena itu keberadaan ordo Odonata yang melimpah disuatu ekosistem menjadi indikator bahwa ekosistem air tersebut masih sedikit cemaran pestisida. Zulhafandi (2020) menyatakan bahwa ordo Odonata banyak ditemukan pada sawah organik dibandingkan konvensional.

Karakteristik komunitas artropoda predator pada padi galur PW, CH, Gil, dan B1 umur tanaman padi 14-56 HST diketahui bahwa galur padi Gil pada umur 28 HST tidak ditemukan artropoda predator (Tabel 5). Hal ini dilihat dari jumlah individu, jumlah spesies, indeks keanekaragaman $\quad\left(\mathrm{H}^{\prime}\right)$, nilai indeks dominasi spesies dan kemerataan spesies yang nilainya $0 . \quad$ Nilai indeks keanekaragaman tertinggi pada galur PW dengan nilai 1,61 umur padi 56 HST. Nilai indeks keanekaragaman tinggi menjadi indikator bahwa suatu ekosistem stabil. Hal ini dapat dilihat dari banyaknya jumlah spesies, tingginya nilai indeks kemerataan. 
Tabel 1. Spesies artropoda predator penghuni tajuk tanaman padi ada beberapa galur padi rakitan Politeknik Negeri Lampung umur padi 14 HST

\begin{tabular}{|c|c|c|c|c|c|c|c|c|c|c|c|c|c|c|c|c|c|c|}
\hline \multirow{2}{*}{ No } & \multirow{2}{*}{ Artropoda } & & \multicolumn{16}{|c|}{ Galur padi } \\
\hline & & & $\mathrm{PW}$ & $\mathrm{CH}$ & Gil & B1 & B2 & B3 & B4 & B7 & D2 & D3 & F3 & $\mathrm{F} 4$ & $\mathrm{H} 1$ & $\mathrm{H} 4$ & $\mathrm{~K}$ & $\mathrm{~L} 2$ \\
\hline & $\begin{array}{l}\text { Arachnida } \\
\text { Oxyopidae }\end{array}$ & & & & & & & & & & & & & & & & & \\
\hline 1 & $\begin{array}{l}\text { Oxyophes javanus } \\
\text { Tetragnathidae }\end{array}$ & & $\sqrt{ }$ & - & - & - & - & - & - & - & - & - & $\sqrt{ }$ & - & - & - & - & - \\
\hline 2 & Tetragnatha javana & & - & - & - & - & - & - & - & - & - & $\sqrt{ }$ & - & - & - & - & $\sqrt{ }$ & - \\
\hline 3 & T. Virescens & & $\sqrt{ }$ & - & $\sqrt{ }$ & - & - & - & $\sqrt{ }$ & - & - & - & - & - & - & $\sqrt{ }$ & - & - \\
\hline 4 & $\begin{array}{l}\text { T. maxilosa } \\
\text { Lycosidae }\end{array}$ & & - & - & $\sqrt{ }$ & - & - & - & - & - & - & - & - & - & - & - & - & $\sqrt{ }$ \\
\hline 5 & Athypena sp. & & - & $\sqrt{ }$ & - & - & - & - & - & - & - & - & - & - & - & - & - & $\sqrt{ }$ \\
\hline 6 & $\begin{array}{l}\text { Pardosa pseudoannulata } \\
\text { Hemiptera } \\
\text { Gerroidea }\end{array}$ & & - & - & - & - & - & - & - & - & - & $\sqrt{ }$ & - & - & - & - & - & - \\
\hline 7 & $\begin{array}{l}\text { Microvelia douglasi } \\
\text { Odonata } \\
\text { Coenagrionidae }\end{array}$ & & - & - & - & $\sqrt{ }$ & $\sqrt{ }$ & $\sqrt{ }$ & - & - & $\sqrt{ }$ & $\sqrt{ }$ & - & - & - & - & - & $\sqrt{ }$ \\
\hline 8 & Agriocnemis pygmaea & & - & - & - & - & - & - & $\sqrt{ }$ & - & $\sqrt{ }$ & - & - & - & $\sqrt{ }$ & - & - & - \\
\hline 9 & A. femina & & - & - & - & - & - & - & - & - & - & - & - & - & - & - & - & - \\
\hline 10 & $\begin{array}{l}\text { A. pieris } \\
\text { Coleoptera } \\
\text { Coccinellidae }\end{array}$ & & - & - & - & - & - & - & - & - & - & - & - & - & - & - & - & - \\
\hline 11 & Verania lineata & & - & $\sqrt{ }$ & - & - & - & - & - & - & - & - & - & - & - & - & - & - \\
\hline 12 & $\begin{array}{l}\text { Menochillus sexmachulatus } \\
\text { Chrysomelidae }\end{array}$ & - & & - & - & - & - & - & - & - & - & - & - & - & - & - & - & - \\
\hline 13 & $\begin{array}{l}\text { Hispella atra } \\
\text { Staphylinidae }\end{array}$ & & - & - & - & - & - & - & - & - & - & - & - & - & - & - & - & - \\
\hline 14 & Paederus fuscipes & & - & - & - & - & - & - & - & - & - & - & - & - & - & - & - & - \\
\hline
\end{tabular}


Tabel 2. Spesies artropoda predator penghuni tajuk tanaman padi penghuni tajuk tanaman padi pada beberapa galur padi rakitan Politeknik Negeri Lampung umur padi 28 HST

\begin{tabular}{|c|c|c|c|c|c|c|c|c|c|c|c|c|c|c|c|c|c|}
\hline \multirow{2}{*}{ No } & \multirow{2}{*}{ Artropoda } & \multicolumn{16}{|c|}{ Galur padi } \\
\hline & & PW & $\mathrm{CH}$ & Gil & B1 & $\mathrm{B} 2$ & B3 & B4 & B7 & D2 & D3 & F3 & $\mathrm{F} 4$ & H1 & $\mathrm{H} 4$ & $\mathrm{~K}$ & $\mathrm{~L} 2$ \\
\hline & Arachnida & & & & & & & & & & & & & & & & \\
\hline & Oxyopidae & & & & & & & & & & & & & & & & \\
\hline \multirow[t]{2}{*}{1} & Oxyophes javanus & - & - & - & $\sqrt{ }$ & - & - & - & - & - & - & - & - & - & $\sqrt{ }$ & $\sqrt{ }$ & - \\
\hline & Tetragnathidae & & & & & & & & & & & & & & & & \\
\hline 2 & Tetragnatha javana & - & - & - & - & - & - & - & - & - & - & - & - & - & - & - & $\sqrt{ }$ \\
\hline 3 & T. virescens & $\sqrt{ }$ & - & - & - & $\sqrt{ }$ & $\sqrt{ }$ & - & - & - & $\sqrt{ }$ & - & $\sqrt{ }$ & - & $\sqrt{ }$ & - & $\sqrt{ }$ \\
\hline \multirow[t]{2}{*}{4} & T. maxilosa & - & - & - & $\sqrt{ }$ & $\sqrt{ }$ & - & - & - & - & - & - & - & - & - & $\sqrt{ }$ & - \\
\hline & Lycosidae & & & & & & & & & & & & & & & & \\
\hline 5 & Athypena sp. & - & $\sqrt{ }$ & - & - & - & - & - & - & - & - & - & - & - & - & - & - \\
\hline \multirow[t]{3}{*}{6} & Pardosa pseudoannulata & - & - & - & $\sqrt{ }$ & - & - & - & - & - & - & - & - & - & - & $\sqrt{ }$ & - \\
\hline & Hemiptera & & & & & & & & & & & & & & & & \\
\hline & Gerroidea & & & & & & & & & & & & & & & & \\
\hline \multirow[t]{3}{*}{7} & Microvelia douglasi & - & - & - & - & - & - & - & - & - & - & - & - & - & - & - & - \\
\hline & Odonata & & & & & & & & & & & & & & & & \\
\hline & Coenagrionidae & & & & & & & & & & & & & & & & \\
\hline 8 & Agriocnemis pygmaea & - & - & - & - & - & - & - & - & - & $\sqrt{ }$ & - & - & - & - & - & - \\
\hline 9 & A. femina & - & - & - & - & - & - & - & - & - & - & $\sqrt{ }$ & - & - & - & - & - \\
\hline \multirow[t]{3}{*}{10} & A. pieris & - & - & - & - & - & - & - & - & - & - & - & - & - & - & - & - \\
\hline & Coleoptera & & & & & & & & & & & & & & & & \\
\hline & Coccinellidae & & & & & & & & & & & & & & & & \\
\hline 11 & Verania lineata & - & - & - & - & $\sqrt{ }$ & - & - & - & - & $\sqrt{ }$ & - & - & - & - & - & - \\
\hline \multirow[t]{2}{*}{12} & Menochillus sexmachulatus & - & - & - & - & - & - & - & - & - & - & - & - & - & - & - & - \\
\hline & Chrysomelidae & & & & & & & & & & & & & & & & \\
\hline \multirow[t]{2}{*}{13} & Hispella atra & - & - & - & - & $\sqrt{ }$ & - & - & - & - & - & - & - & - & - & - & - \\
\hline & Staphylinidae & & & & & & & & & & & & & & & & \\
\hline 14 & Paederus fuscipes & - & - & - & - & - & - & - & - & - & - & - & - & - & - & - & - \\
\hline
\end{tabular}


Tabel 3. Spesies artropoda predator penghuni tajuk tanaman padi penghuni tajuk tanaman padi pada beberapa galur padi rakitan Politeknik Negeri Lampung umur padi $42 \mathrm{HST}$

\begin{tabular}{|c|c|c|c|c|c|c|c|c|c|c|c|c|c|c|c|c|c|}
\hline \multirow{2}{*}{ No } & \multirow{2}{*}{ Artropoda } & \multicolumn{16}{|c|}{ Galur padi } \\
\hline & & PW & $\mathrm{CH}$ & Gil & $\mathrm{B} 1$ & $\mathrm{~B} 2$ & B3 & B4 & B7 & D2 & D3 & F3 & $\mathrm{F} 4$ & $\mathrm{H} 1$ & $\mathrm{H} 4$ & $\mathrm{~K}$ & $\mathrm{~L} 2$ \\
\hline & $\begin{array}{l}\text { Arachnida } \\
\text { Oxyopidae }\end{array}$ & & & & & & & & & & & & & & & & \\
\hline 1 & Oxyophes javanus & - & - & - & - & - & - & - & - & - & $\sqrt{ }$ & - & - & - & - & - & - \\
\hline & Tetragnathidae & & & & & & & & & & & & & & & & \\
\hline 2 & Tetragnatha javana & - & $\sqrt{ }$ & $\sqrt{ }$ & - & - & - & $\sqrt{ }$ & - & - & - & - & - & - & - & - & - \\
\hline 3 & T. virescens & $\sqrt{ }$ & $\sqrt{ }$ & - & $\sqrt{ }$ & - & $\sqrt{ }$ & $\sqrt{ }$ & - & $\sqrt{ }$ & $\sqrt{ }$ & $\sqrt{ }$ & $\sqrt{ }$ & $\sqrt{ }$ & $\sqrt{ }$ & $\sqrt{ }$ & - \\
\hline 4 & $\begin{array}{l}\text { T. maxilosa } \\
\text { Lycosidae }\end{array}$ & $\sqrt{ }$ & - & - & - & $\sqrt{ }$ & - & - & $\sqrt{ }$ & $\sqrt{ }$ & - & - & - & - & - & $\sqrt{ }$ & $\sqrt{ }$ \\
\hline 5 & Athypena sp. & - & - & - & - & - & - & - & - & - & - & - & - & - & - & - & - \\
\hline 6 & $\begin{array}{l}\text { Pardosa pseudoannulata } \\
\text { Hemiptera } \\
\text { Gerroidea }\end{array}$ & - & - & - & - & - & - & - & - & - & - & - & - & - & - & - & - \\
\hline 7 & $\begin{array}{l}\text { Microvelia douglasi } \\
\text { Odonata } \\
\text { Coenagrionidae }\end{array}$ & - & - & - & - & - & - & - & - & - & - & - & - & - & - & - & - \\
\hline 8 & Agriocnemis pygmaea & $\sqrt{ }$ & $\sqrt{ }$ & - & - & $\sqrt{ }$ & $\sqrt{ }$ & $\sqrt{ }$ & $\sqrt{ }$ & $\sqrt{ }$ & - & $\sqrt{ }$ & $\sqrt{ }$ & - & $\sqrt{ }$ & $\sqrt{ }$ & - \\
\hline 9 & A. femina & - & - & - & - & - & $\sqrt{ }$ & - & - & $\sqrt{ }$ & - & - & - & - & $\sqrt{ }$ & - & - \\
\hline 10 & $\begin{array}{l}\text { A. pieris } \\
\text { Coleoptera } \\
\text { Coccinellidae }\end{array}$ & $\sqrt{ }$ & - & $\sqrt{ }$ & $\sqrt{ }$ & $\sqrt{ }$ & - & - & $\sqrt{ }$ & - & - & - & - & - & $\sqrt{ }$ & - & - \\
\hline 11 & Verania lineata & - & - & - & - & - & - & - & - & - & - & - & - & - & - & - & - \\
\hline 12 & $\begin{array}{l}\text { Menochillus sexmachulatus } \\
\text { Chrysomelidae }\end{array}$ & - & - & - & - & - & - & $\sqrt{ }$ & - & - & - & - & - & - & - & - & - \\
\hline 13 & $\begin{array}{l}\text { Hispella atra } \\
\text { Staphylinidae }\end{array}$ & - & - & - & - & - & - & - & - & - & - & - & - & - & - & - & - \\
\hline 14 & Paederus fuscipes & - & - & - & - & - & - & - & - & - & - & - & - & - & - & - & $\sqrt{ }$ \\
\hline
\end{tabular}


Tabel 4. Spesies artropoda predator penghuni tajuk tanaman padi penghuni tajuk tanaman padi pada beberapa galur padi rakitan Politeknik Negeri Lampung umur padi 56 HST

\begin{tabular}{|c|c|c|c|c|c|c|c|c|c|c|c|c|c|c|c|c|c|c|}
\hline \multirow{2}{*}{ No } & \multirow{2}{*}{ Artropoda } & \multicolumn{17}{|c|}{ Galur padi } \\
\hline & & & PW & $\mathrm{CH}$ & Gil & B1 & B2 & B3 & B4 & B7 & D2 & D3 & F3 & $\mathrm{F} 4$ & $\mathrm{H} 1$ & $\mathrm{H} 4$ & $\mathrm{~K}$ & L2 \\
\hline & $\begin{array}{l}\text { Arachnida } \\
\text { Oxyopidae }\end{array}$ & & & & & & & & & & & & & & & & & \\
\hline 1 & $\begin{array}{l}\text { Oxyophes javanus } \\
\text { Tetraghnathidae }\end{array}$ & & - & $\sqrt{ }$ & - & - & $\sqrt{ }$ & - & - & - & - & $\sqrt{ }$ & - & - & $\sqrt{ }$ & - & - & $\sqrt{ }$ \\
\hline 2 & Tetragnatha javana & & - & $\sqrt{ }$ & $\sqrt{ }$ & - & - & - & $\sqrt{ }$ & - & - & - & - & - & - & - & - & - \\
\hline 3 & T. virescens & & $\sqrt{ }$ & - & - & $\sqrt{ }$ & - & $\sqrt{ }$ & $\sqrt{ }$ & - & - & $\sqrt{ }$ & - & $\sqrt{ }$ & $\sqrt{ }$ & $\sqrt{ }$ & $\sqrt{ }$ & - \\
\hline 4 & $\begin{array}{l}\text { T. maxilosa } \\
\text { Lycosidae }\end{array}$ & & $\sqrt{ }$ & - & $\sqrt{ }$ & - & $\sqrt{ }$ & - & $\sqrt{ }$ & $\sqrt{ }$ & $\sqrt{ }$ & - & - & - & - & - & $\sqrt{ }$ & $\sqrt{ }$ \\
\hline 5 & Athypena sp. & & - & - & - & - & - & - & - & - & - & - & - & - & - & - & - & - \\
\hline 6 & $\begin{array}{l}\text { Pardosa pseudoannulata } \\
\text { Hemiptera } \\
\text { Gerroidea }\end{array}$ & & - & - & - & - & - & - & - & - & - & - & - & - & - & - & - & - \\
\hline 7 & $\begin{array}{l}\text { Microvelia douglasi } \\
\text { Odonata } \\
\text { Coenagrionidae }\end{array}$ & & $\sqrt{ }$ & - & - & - & - & - & - & - & - & - & - & - & - & - & - & - \\
\hline 8 & Agriocnemis pygmaea & & $\sqrt{ }$ & $\sqrt{ }$ & - & - & $\sqrt{ }$ & $\sqrt{ }$ & $\sqrt{ }$ & $\sqrt{ }$ & $\sqrt{ }$ & - & $\sqrt{ }$ & $\sqrt{ }$ & - & $\sqrt{ }$ & $\sqrt{ }$ & - \\
\hline 9 & A. femina & & - & - & - & - & - & $\sqrt{ }$ & - & - & - & - & - & - & - & $\sqrt{ }$ & - & - \\
\hline 10 & $\begin{array}{l}\text { A. pieris } \\
\text { Coleoptera } \\
\text { Coccinellidae }\end{array}$ & & $\sqrt{ }$ & - & $\sqrt{ }$ & $\sqrt{ }$ & $\sqrt{ }$ & - & - & $\sqrt{ }$ & $\sqrt{ }$ & - & - & - & - & - & - & - \\
\hline 11 & Verania lineata & & - & - & - & - & $\sqrt{ }$ & - & - & - & - & - & - & - & - & - & - & - \\
\hline 12 & $\begin{array}{l}\text { Menochillus sexmachulatus } \\
\text { Chrysomelidae }\end{array}$ & - & & - & - & - & - & - & $\sqrt{ }$ & - & - & - & - & - & - & - & - & - \\
\hline 13 & $\begin{array}{l}\text { Hispella atra } \\
\text { Staphylinidae }\end{array}$ & & - & - & - & - & - & - & - & - & - & - & - & - & - & - & - & - \\
\hline 14 & Paederus fuscipes & & - & $\sqrt{ }$ & - & - & - & $\sqrt{ }$ & - & - & $\sqrt{ }$ & $\sqrt{ }$ & - & - & - & $\sqrt{ }$ & $\sqrt{ }$ & $\sqrt{ }$ \\
\hline
\end{tabular}

Keterangan: $(\sqrt{ })$ : ada; $(-)$ : tidak ada 
Tabel 5. Karakteristik komunitas artropoda predator pada beberapa galur padi PW, CH, Gil, dan B1 rakitan Politeknik Negeri Lampung umur padi 14-56 HST

\begin{tabular}{|c|c|c|c|c|}
\hline \multirow{2}{*}{ Karakteristik Komunitas } & \multicolumn{4}{|c|}{ Umur hari setelah tanam (HST) } \\
\hline & 14 & 28 & 42 & 56 \\
\hline \multicolumn{5}{|l|}{ Galur PW } \\
\hline Jumlah individu (ekor/9 ayunan ganda) (N) & 2,00 & 2,00 & 4,00 & 5,00 \\
\hline Jumlah spesies (S) & 2,00 & 1,00 & 4,00 & 5,00 \\
\hline Indeks keanekaragaman spesies ( $\left.\mathrm{H}^{\prime}\right)$ & 0,69 & 0,00 & 1,39 & 1,61 \\
\hline Indeks dominasi spesies (d) & 0,25 & 1,00 & 0,25 & 0,20 \\
\hline Indeks kemerataan spesies (E) & 1,00 & 0,00 & 0,91 & 0,91 \\
\hline \multicolumn{5}{|l|}{ Galur $\mathrm{CH}$} \\
\hline Jumlah individu (ekor/9 ayunan ganda) (N) & 2,00 & 1,00 & 4,00 & 6,00 \\
\hline Jumlah spesies (S) & 2,00 & 1,00 & 3,00 & 4,00 \\
\hline Indeks keanekaragaman spesies ( $\left.\mathrm{H}^{\prime}\right)$ & 0,69 & 0,00 & 1,04 & 0,96 \\
\hline Indeks dominasi spesies (d) & 0,50 & 1,00 & 0,50 & 0,33 \\
\hline Indeks kemerataan spesies (E) & 0,99 & 0,00 & 0,95 & 0,70 \\
\hline \multicolumn{5}{|l|}{ Galur Gil } \\
\hline Jumlah individu (ekor/9 ayunan ganda) (N) & 5,00 & 0,00 & 2,00 & 3,00 \\
\hline Jumlah spesies (S) & 2,00 & 0,00 & 2,00 & 3,00 \\
\hline Indeks keanekaragaman spesies ( $\left.\mathrm{H}^{\prime}\right)$ & 0,67 & 0,00 & 0,69 & 1,10 \\
\hline Indeks dominasi spesies (d) & 0,60 & 0,00 & 0,50 & 0,33 \\
\hline Indeks kemerataan spesies (E) & 0,97 & 0,00 & 0,91 & 1,00 \\
\hline \multicolumn{5}{|l|}{ Galur B1 } \\
\hline Jumlah individu (ekor/9 ayunan ganda) (N) & 1,00 & 5,00 & 3,00 & 4,00 \\
\hline Jumlah spesies (S) & 1,00 & 3,00 & 2,00 & 3,00 \\
\hline Indeks keanekaragaman spesies ( $\left.\mathrm{H}^{\prime}\right)$ & 0,00 & 0,95 & 0,64 & 1,04 \\
\hline Indeks dominasi spesies (d) & 1,00 & 0,60 & 0,67 & 0,50 \\
\hline Indeks kemerataan spesies (E) & 0,00 & 0,87 & 0,92 & 0,95 \\
\hline
\end{tabular}

Tingginya nilai indeks kemerataan menjelaskan bahwa spesies pada suatu ekosistem itu tidak didominasi oleh satu spesies tertentu saja. Sehingga semakin tinggi nilai indeks kemerataan maka akan berbanding terbalik dengan rendahnya nilai indeks dominasi spesies $\mathrm{di}$ ekosistem tersebut. Rendahnya nilai indeks keanekaragaman pada suatu ekosistem biasanya dipengaruhi oleh aplikasi insektisida kimia untuk mengendalikan jenis hama. Aplikasi indektisida kimia ini yang memberikan dampak negatif terhadap terbunuhnya serangga non target seperti predator ataupun parasitoid. Laba-laba predator penghuni tajuk tanaman padi menjadi salah satu artropoda non target dari adanya aplikasi insektisida kimia.

Banyaknya jenis laba-laba predator pada tajuk tanaman padi yang terbunuh akibat terpapar insektisida kimia juga menjadi salah satu faktor menurunnya nilai indeks keanekaragaman artropoda 
predator. Hal ini sejalan dengan penelitian yang dilakukan oleh Gunawan et al. (2015) yang menyatakan bahwa adanya penurunan populasi laba-laba predator pada lahan yang dibudidayakan menggunakan pestisida kimia.

Galur padi B4 dan B7 tidak ditemukan artropoda predator pada umur padi 14 dan $28 \mathrm{HST}$. Jumlah spesies artropoda predator tertinggi adalah 5 spesies dan jumlah individu 6 ekor/9 ayunan ganda. Nilai indeks dominasi spesies terkecil adalah 0,20. Indeks kemerataan artropoda predator pada galur padi B2, B3, B4 dan B7 yang paling tinggi adalah 1,26. Artropoda predator menjadi salah satu faktor biotik yang mampu menekan populasi hama yang menyerang tanaman padi. Keberadaan artropoda predator di ekosistem padi sangat dipengaruhi oleh sistem budidaya padi yang diterapkan. Budidaya padi secara konvensional dengan menggunakan insektisida kimia sebagai pengendalian hama akan berpengaruh terhadap rendahnya indeks keanekaragaman artropoda predator yang menghuni ekosistem padi. Artropoda predator seperti laba-laba dan serangga predator pada tajuk tanaman terpapar oleh aplikasi tersebut. Indeks keanekaragaman artropoda predator pada galur padi B2, B3, B4, dan B7 umur padi 14-42 HST rendah. Sedangkan pada umur padi 56 hst indek keanekaragaman meningkat pada galur padi B2 dan B4 (Tabel 6). Rendahnya nilai indeks keanekaragamaan artropoda predator pada beberapa galur tersebut karena sistem budidaya yang digunakan adalah sistem budidaya konvensional dengan menggunakan insektisida kimia untuk mengendalikan hama seperti wereng coklat, hama putih palsu, walang sangit ataupun penggerek batang padi.

Galur padi F4 memiliki nilai indeks keanekaragaman yang rendah dibandingkan dengan galur padi D2, D3, F3 dan F4. Sedangkan jumlah individu dan jumlah spesies paling sedikit pada galur F3 umur 56 HST (Tabel 7). Galur padi F4 pada pengamatan padi umur 14 HST tidak ditemukan keberadaan artropoda predator dilihat dari tidak adanya nilai indeks keanekaragaman, jumlah spesies, jumlah individu, indeks dominasi spesies, dan indeks kemerataan. Hal ini dikarenakan pada umur tanaman 14 HST tanaman masih kecil sehingga jumlah populasi hama juga masih sedikit. Jumlah populasi hama yang sedikit juga akan bertaut dengan jumlah artropoda predator. 
Tabel 6. Karakteristik komunitas artropoda predator pada beberapa galur padi B2, B3, B4, dan B7 rakitan Politeknik Negeri Lampung umur padi 14-56 HST

\begin{tabular}{|c|c|c|c|c|}
\hline \multirow{2}{*}{ Karakteristik Komunitas } & \multicolumn{4}{|c|}{ Umur hari setelah tanam (HST) } \\
\hline & 14 & 28 & 42 & 56 \\
\hline \multicolumn{5}{|l|}{ Galur B2 } \\
\hline Jumlah individu (ekor/9 ayunan ganda) (N) & 1,00 & 4,00 & 4,00 & 6,00 \\
\hline Jumlah spesies (S) & 1,00 & 4,00 & 3,00 & 5,00 \\
\hline Indeks keanekaragaman spesies (H') & 0,00 & 1,39 & 1,04 & 1,56 \\
\hline Indeks dominasi spesies (d) & 1,00 & 0,25 & 0,50 & 0,33 \\
\hline Indeks kemerataan spesies (E) & 0,00 & 0,91 & 0,95 & 0,97 \\
\hline \multicolumn{5}{|l|}{ Galur B3 } \\
\hline Jumlah individu (ekor/9 ayunan ganda) (N) & 2,00 & 3,00 & 4,00 & 4,00 \\
\hline Jumlah spesies (S) & 1,00 & 1,00 & 3,00 & 3,00 \\
\hline Indeks keanekaragaman spesies (H') & 0,00 & 0,00 & 1,04 & 1,39 \\
\hline Indeks dominasi spesies (d) & 1,00 & 1,00 & 0,50 & 0,50 \\
\hline Indeks kemerataan spesies (E) & 0,00 & 0,00 & 0,95 & 1,26 \\
\hline \multicolumn{5}{|l|}{ Galur B4 } \\
\hline Jumlah individu (ekor/9 ayunan ganda) (N) & 3,00 & 0,00 & 6,00 & 5,00 \\
\hline Jumlah spesies (S) & 2,00 & 0,00 & 5,00 & 5,00 \\
\hline Indeks keanekaragaman spesies ( $\left.\mathrm{H}^{\prime}\right)$ & 0,64 & 0,00 & 1,26 & 1,93 \\
\hline Indeks dominasi spesies (d) & 0,67 & 0,00 & 0,33 & 0,20 \\
\hline Indeks kemerataan spesies (E) & 0,92 & 0,00 & 0,78 & 1,20 \\
\hline \multicolumn{5}{|l|}{ Galur B7 } \\
\hline Jumlah individu (ekor/9 ayunan ganda) (N) & 0,00 & 0,00 & 6,00 & 6,00 \\
\hline Jumlah spesies (S) & 0,00 & 0,00 & 3,00 & 3,00 \\
\hline Indeks keanekaragaman spesies (H') & 0,00 & 0,00 & 1,01 & 1,01 \\
\hline Indeks dominasi spesies (d) & 0,00 & 0,00 & 0,33 & 0,50 \\
\hline Indeks kemerataan spesies (E) & 0,00 & 0,00 & 0,92 & 0,92 \\
\hline \multirow{4}{*}{$\begin{array}{l}\text { Pengamatan artropoda predator } \\
\text { umur padi 14-56 HST diketahui bahwa } \\
\text { galur padi H1 umur padi } 28 \text { HST tidak } \\
\text { ditemukan artropoda predator (Tabel 8). }\end{array}$} & \multicolumn{4}{|c|}{ peningkatan $\quad$ nilai $\quad$ indeks } \\
\hline & \multicolumn{4}{|c|}{ keanekaragaman $\left(\mathrm{H}^{\prime}\right)$ artropoda predator } \\
\hline & \multicolumn{4}{|c|}{ terjadi pada pengamatan saat umur padi } \\
\hline & \multicolumn{4}{|c|}{56 HST (Gambar 1). Nilai indeks } \\
\hline Galur padi H4 memiliki nilai indeks & \multirow{2}{*}{\multicolumn{4}{|c|}{$\begin{array}{l}\text { keanekaragaman rendah akibat dari } \\
\text { aplikasi insektisida kimia. Hal ini terlihat }\end{array}$}} \\
\hline keanekaragaman tertinggi dibandingkan & & & & \\
\hline dengan nilai indeks keanekaragaman & \multirow{2}{*}{\multicolumn{4}{|c|}{$\begin{array}{l}\text { dari nilai indeks keanekaragaman } \\
\text { artropoda predator pada galur padi }\end{array}$}} \\
\hline artropoda predator galur $\mathrm{H} 1, \mathrm{~K}$, dan $\mathrm{L} 2$ & & & & \\
\hline pada umur tanaman padi 56 HST. & \multicolumn{4}{|c|}{ sekitar 0,00-1,93. Amrullah (2018) } \\
\hline Nilai indeks keanekaragaman $\left(\mathrm{H}^{\prime}\right)$ & \multirow{2}{*}{\multicolumn{4}{|c|}{$\begin{array}{l}\text { menyatakan bahwa nilai indeks } \\
\text { keanekaragaman }\left(\mathrm{H}^{\prime}\right) \text { dengan skala } 0,61 \text { - }\end{array}$}} \\
\hline artropoda predator terjadi secara & & & & \\
\hline fluktuatif dan tergolong rendah dan & \multirow{2}{*}{\multicolumn{4}{|c|}{$\begin{array}{l}\text { 1,2 memiliki struktur komunitas yang } \\
\text { cukup stabil dan kategori buruk. }\end{array}$}} \\
\hline iap galur padi & & & & \\
\hline
\end{tabular}

Politeknik Negeri Lampung pada setiap

umur padi 14-56 HST. Rata-rata 
Tabel 7. Karakteristik komunitas artropoda predator pada beberapa galur padi D2, D3, F3, dan F4 rakitan Politeknik Negeri Lampung umur padi 14-56 HST

\begin{tabular}{lcccc}
\hline \multirow{2}{*}{ Karakteristik Komunitas } & \multicolumn{4}{c}{ Umur hari setelah tanam (HST) } \\
\cline { 2 - 5 } & 14 & 28 & 42 & 56 \\
\hline Galur D2 & & & & \\
Jumlah individu (ekor/9 ayunan ganda) (N) & 3,00 & 0,00 & 4,00 & 5,00 \\
Jumlah spesies (S) & 2,00 & 0,00 & 4,00 & 5,00 \\
Indeks keanekaragaman spesies (H') & 0,64 & 0,00 & 1,39 & 1,61 \\
Indeks dominasi spesies (d) & 0,67 & 0,00 & 0,25 & 0,20 \\
Indeks kemerataan spesies (E) & 0,92 & 0,00 & 0,91 & 1,00 \\
\hline Galur D3 & & & & \\
Jumlah individu (ekor/9 ayunan ganda) (N) & 3,00 & 3,00 & 2,00 & 4,00 \\
Jumlah spesies (S) & 3,00 & 3,00 & 2,00 & 4,00 \\
Indeks keanekaragaman spesies (H') & 1,10 & 1,10 & 0,69 & 1,39 \\
Indeks dominasi spesies (d) & 0,33 & 0,33 & 0,50 & 0,25 \\
Indeks kemerataan spesies (E) & 1,00 & 1,00 & 0,91 & 1,00 \\
\hline Galur F3 & & & & \\
Jumlah individu (ekor/9 ayunan ganda) (N) & 1,00 & 1,00 & 2,00 & 1,00 \\
Jumlah spesies (S) & 1,00 & 1,00 & 2,00 & 1,00 \\
Indeks keanekaragaman spesies (H') & 0,00 & 0,00 & 0,69 & 0,00 \\
Indeks dominasi spesies (d) & 1,00 & 1,00 & 0,50 & 1,00 \\
Indeks kemerataan spesies (E) & 0,00 & 0,00 & 0,91 & 0,00 \\
\hline Galur F4 & & & & \\
Jumlah individu (ekor/9 ayunan ganda) (N) & 0,00 & 2,00 & 3,00 & 3,00 \\
Jumlah spesies (S) & 0,00 & 1,00 & 2,00 & 2,00 \\
Indeks keanekaragaman spesies (H') & 0,00 & 0,00 & 0,64 & 0,64 \\
Indeks dominasi spesies (d) & 0,00 & 1,00 & 0,67 & 0,25 \\
Indeks kemerataan spesies (E) & 0,00 & 0,00 & 0,92 & 0,92 \\
\hline
\end{tabular}

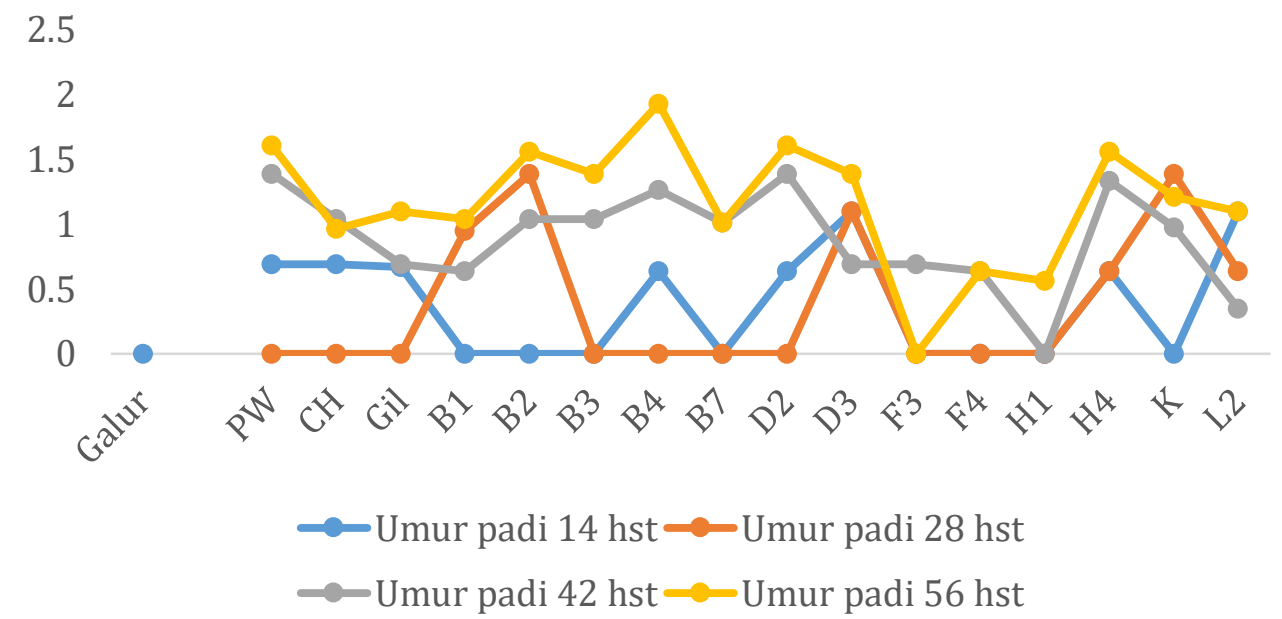

Gambar 1. Grafik nilai indeks keanekaragaman $\left(\mathrm{H}^{\prime}\right)$ artropoda predator pada galur padi rakitan Politeknik Negeri Lampung umur 14-56 hst 
Tabel 8. Karakteristik komunitas artropoda predator pada beberapa galur padi D2, D3, F3, dan F4 rakitan Politeknik Negeri Lampung umur padi 14-56 HST

\begin{tabular}{|c|c|c|c|c|}
\hline \multirow{2}{*}{ Karakteristik Komunitas } & \multicolumn{4}{|c|}{ Umur hari setelah tanam (HST) } \\
\hline & 14 & 28 & 42 & 56 \\
\hline \multicolumn{5}{|l|}{ Galur H1 } \\
\hline Jumlah individu (ekor/9 ayunan ganda) (N) & 2,00 & 0,00 & 1,00 & 4,00 \\
\hline Jumlah spesies (S) & 1,00 & 0,00 & 1,00 & 2,00 \\
\hline Indeks keanekaragaman spesies ( $\left.\mathrm{H}^{\prime}\right)$ & 0,00 & 0,00 & 0,00 & 0,56 \\
\hline Indeks dominasi spesies (d) & 1,00 & 0,00 & 1,00 & 0,75 \\
\hline Indeks kemerataan spesies (E) & 0,00 & 0,00 & 0,00 & 0,81 \\
\hline \multicolumn{5}{|l|}{ Galur H4 } \\
\hline Jumlah individu (ekor/9 ayunan ganda) $(\mathrm{N})$ & 3,00 & 3,00 & 5,00 & 6,00 \\
\hline Jumlah spesies (S) & 2,00 & 2,00 & 4,00 & 5,00 \\
\hline Indeks keanekaragaman spesies $\left(\mathrm{H}^{\prime}\right)$ & 0,64 & 0,64 & 1,33 & 1,56 \\
\hline Indeks dominasi spesies (d) & 0,67 & 0,67 & 0,40 & 0,33 \\
\hline Indeks kemerataan spesies (E) & 0,92 & 0,92 & 0,96 & 0,97 \\
\hline \multicolumn{5}{|l|}{ Galur K } \\
\hline Jumlah individu (ekor/9 ayunan ganda) (N) & 1,00 & 4,00 & 8,00 & 8,00 \\
\hline Jumlah spesies (S) & 1,00 & 4,00 & 3,00 & 4,00 \\
\hline Indeks keanekaragaman spesies ( $\left.\mathrm{H}^{\prime}\right)$ & 0,00 & 1,39 & 0,97 & 1,21 \\
\hline Indeks dominasi spesies (d) & 1,00 & 0,25 & 0,38 & 0,50 \\
\hline Indeks kemerataan spesies (E) & 0,00 & 0,91 & 0,89 & 0,88 \\
\hline \multicolumn{5}{|l|}{ Galur L2 } \\
\hline Jumlah individu (ekor/9 ayunan ganda) (N) & 3,00 & 3,00 & 2,00 & 3,00 \\
\hline Jumlah spesies $(\mathrm{S})$ & 3,00 & 2,00 & 2,00 & 3,00 \\
\hline Indeks keanekaragaman spesies (H') & 1,10 & 0,64 & 0,35 & 1,10 \\
\hline Indeks dominasi spesies (d) & 0,33 & 0,67 & 0,50 & 0,33 \\
\hline Indeks kemerataan spesies (E) & 1,00 & 0,92 & 0,50 & 1,00 \\
\hline
\end{tabular}

\section{KESIMPULAN}

Dari hasil penelitian ini dapat disimpulkan bahwa artropoda predator yang ditemukan pada galur padi Pandan Wangi (PW), Ciherang (CH), B1, B2, B3, B4, B7, D2, D3, F3, F4, H1, H4, K, dan L2 dengan 2 varietas unggul pembanding yaitu Ciherang $(\mathrm{CH})$ dan Gilirang (Gil) adalah Oxyopes javanus, Tetragnatha javana, T. virescens, T. maxilosa, Pardosa pseudoannulata, Athypena sp., dan serangga predator seperti Microvelia douglasi, Agriocnemis pygmaea, A. femina,
A. pieris, dan Verania lineata, Menochillus sexmachulatus, Hispella atra, dan Paederus fuscipes. Nilai indeks keanekaragaman pada setiap galur padi fluktuatif dan berkisar dari rendah ke sedang dan hasil analisis nilai indeks keanekaragaman $\left(\mathrm{H}^{\prime}\right)$ artropoda predator terjadi secara fluktuatif dan tergolong rendah dan sedang

\section{UCAPAN TERIMA KASIH}

Penulis mengucapkan terima kasih kepada seed teaching farm Program Studi 
Teknologi perbenihan yang telah menyediakan bahan galur padi dan tempat penelitian. Dan penulis ingin mengucapakan terima kasih kepada tim yang telah mendukung penelitian ini.

\section{DAFTAR PUSTAKA}

Amrullah, S.H. (2018). Indeks Keanekaragaman Capung (Insecta: Odonata) sebagai Pengukur Kualitas Lingkungan Sungai dalam Kawasan Taman. Nasional Bantimurung Bulusaraung. Seminar Nasional Hasil Penelitian (SNP2M) 2018, pp. 86-91. URL: https://journal.unnes.ac.id/nju/ind ex.php/JM/article/download/1921 $1 / 9193$.

Arifin, M. (2012). Predator Hama Tanaman Dan Penular Penyakit Dermatitis. Pengembangan Inovasi Pertanian 5(1), 58-64.

Baehaki, S.E. (2011). Strategi Fundamental Pengendalian Hama Wereng Batang Coklat Dalam Pengamanan. Pengembangan Inovasi Pertanian 4(1), 63-75.

Baehaki, S.E. (2012). Perkembangan Biotipe Hama Wereng Coklat pada Tanaman Padi. Iptek Tanaman Pangan 7(1), 8-17.

Baehaki, S.E., \& Mejaya, I.M.J. (2014). Wereng Cokelat sebagai Hama Global Bernilai Ekonomi Tinggi dan Strategi Pengendaliannya. Iptek Tanaman Pangan 9(1), 1-12.

Barrion, A.T., \& Litsinger, J.A. (1990). Taxonomy of Rice Insect Pests and Their Arthropod Parasites and Predator. International Rice Research Institute. Philippines. 580 p.

Barrion, A.T., \& Litsinger, J.A. (1995). Riceland Spiders of South and Southeast Asia. Manila: International Rice Research Institute.

deGunst, J.H. (1957). Indonesia Lady birds. Penggemar alam 36(3), 3-17.

Fitriani. (2016). Keanekaragaman arthropoda pada ekosistem tanaman padi dengan aplikasi pestisida. Agrovital 1(1), 6-8.

Gunawan, C.S., Mudjiono, G., \& Astuti, L.P. (2015). Kelimpahan Populasi Wereng Batang Coklat Nilaparvata lugens Stal. (Homoptera: Delphacidae) dan Laba-Laba Pada Budidaya Tanaman Padi Dengan Penerapan Pengendalian Hama Terpadu dan Konvensional. Jurnal HPT 3(1), 117-122.

Hadlington, P.W., \& Johnsron, J.A. (1987). An Introduction to Australian Insects. South China Co. Hongkong. $116 \mathrm{p}$

Hendrival., Hakim, L., \& Halimuddin. (2017). Komposisi dan keanekaragaman arthropoda predator pada agroekosistem padi. Floratek 12(1), 21-33.

Herlinda, S., Dewi, R., Adam, T., Suwandi, \& Wijaya, A. (2015). Struktur komunitas laba-laba di ekosistem padi ratun: pengaruh aplikasi Beauveria bassiana (Balsamo). Jurnal Entomologi Indonesia 12(2), 91-99. doi: 10.5994/jei.12.2.91.

Herlinda, S., Waluyo, Estuningsih, S.P., \& Irsan, C. (2008). Perbandingan Keanekaragaman Spesies dan Kelimpahan Arthropoda Predator Penghuni Tanah di Sawah Lebak yang Diaplikasi dan Tanpa Aplikasi Insektisida. Journal Entomologi Indonesia 5(2), 96-107.

Hilsenhoff, W.L. (1991). Diversity and classification of insects and Collembola, p.593-664. In J.H. Thorp and A.P. Covich (cds.). Ecology and Classification of North America Freshwater Invertebrates. Academic Press, Inc. San Diego.

Kalsoven, L.G.F. (1981). Pest of Crops in Indonesia. Revised and Translated by van der Laan. PT Ichtiar Baru van Hoeve. Jakarta. $701 \mathrm{p}$

Khodijah, Herlinda, S., Irsan, C., Pujiastuti, Y., \& Thalib, R. (2012). Artropoda Predator Penghuni Ekosistem 
Persawahan Lebak dan Pasang Surut Sumatera Selatan Predatory Arthropods InhabitingFresh Swamp and Tidal Lowland Ecosystem in South Sumatra. Jurnal Lahan Suboptimal 1(1), 57-63.

Kurniawati, N. (2015). Keragaman dan Kelimpahan Musuh Alami Hama pada Habitat Padi yang Dimanipulasi dengan Tumbuhan Berbunga. Ilmu Pertanian 18(1), 3136. doi: 10.22146/ipas.6175.

Lawrence, J.F., \& Britton, E.B. (1994). Australian Beetles. Mealbourne University Press. Victoria. 192 p.

Magurran, A.E. (1987). Ecological Diversity and Its Measurement. New Jersey: Princeton University Press.

Shepard, B.M., Barrion, A.T., Litsinger, J.A. (1991). Friends of the Rice Farmer: Helpful Insects, Spiders, and Pathogens. Manila: International Rice Research Institute.

Zulhafandi. (2020). Keanekaragaman capung (Odonata). Jurnal Ilmu Pertanian 3(1), 34-42.

Zuharah, W.F., \& Maryam, S. (2020). Multifarious Rools of feeding behaviours in roof beetle, Paederuf fuscipes. Sains Malaysiana 49(1), 110. 